\title{
Wildlife-community conflicts in conservation areas in Kenya
}

\author{
Roselyne N. Okech*
}

\section{Abstract}

Kenya is rich in biological diversity to which wildlife resources contribute a significant proportion. Many of the regions with abundant and diverse wildlife communities remaining in East Africa are occupied by pastoralists. Recent studies show that the majority of the local people around protected areas have negative feelings about state policies and conservation programmes. The alienation of grazing land for the exclusive use of wildlife and tourists has a very direct impact upon the pastoralist communities, and prompts them to raise questions about African wildlife policy - as if it leads to a 'people versus animals' conflict. Nevertheless, large areas of pastoral rangelands have been expropriated for exclusive wildlife conservation use. This has commonly been justified by the argument that pastoralists overstock, overgraze and damage their range while wild animals are seen as existing in harmony with their surroundings. Wildlifehuman conflicts, therefore, are a consequence of the problem of resource

\footnotetext{
* Dr Roselyne N. Okech is a visiting lecturer at the University of KwaZulu-Natal from the Sir Wilfred Grenfell College Memorial University of Newfoundland, Canada. Research was undertaken at the University of KwaZulu-Natal, Durban.
} 


\section{Roselyne N. Okech}

utilisation in conservation areas. Such conflicts do not solve this problem, however, but adversely affect the biodiversity. They harm people and property, and lead to the retaliatory killing of wildlife in $82 \%$ of the protected areas. This paper reviews literature that seeks to address the important issue of wildlifehuman conflicts and also explores the aspects of pastoralism and conservation in Kenya.

\section{Introduction}

Kenya's wildlife is one of the richest and most diversified in Africa. Several of its protected areas and wetlands are internationally recognised and protected as World Heritage Sites, Ramsar Sites (since the Convention on Wetlands was adopted in the Iranian city of Ramsar) and Man and Biosphere Reserves. Kenya's wildlife resource also constitutes a unique natural heritage that is of great importance both nationally and globally. Wildlife resources contribute directly and indirectly to the local and national economy through revenue generation and wealth creation (Ministry of Tourism and Wildlife 2007). For example, in the year ending 30 June 2006, wildlife accounted for $70 \%$ of the gross tourism earnings, 25\% of the Gross Domestic Product (GDP) and more than $10 \%$ of total formal sector employment. On the whole, Kenyan people are depending on wildlife for livelihood, shelter, and for other ecosystem goods and services. Wildlife also fulfils critical ecological functions that are important for the interconnected web of life-supporting systems. Significantly, Kenya's major water towers are found in wildlife-protected areas. Wildlife also has sociocultural and aesthetic values. Indeed, any adverse impacts on the ecosystem can dramatically alter humans' capacity to survive.

One of the major threats facing Kenya is the loss of biological diversity. Land use changes favouring agriculture and rural and urban development have led to the reduction and modification of wild areas, resulting in the extinction of or threat of extinction to wildlife species and natural areas which serve as their habitat. Kenya's great reservoir of wildlife is increasingly under threat and opportunities are lost for its contribution to the creation of growth, wealth and employment. According to Irandu (2003), the local comunities living near and around the national parks and game reserves are first to pay the price for wildlife 


\section{Wildlife-community conflicts in conservation areas in Kenya}

conservation through the destruction of their property, and through death or injuries caused by wild animals. This is especially the case in the big national parks and game reserves in Kenya. According to Munyori (1992a:110; 1992b:16), Sindiga (1999) and Sindiyo (1992:76), wildlife-human conflicts are a problem of resource utilisation in conservation areas. Increasing scholarly attention and policy initiatives attest to the seriousness of the problem. Recent studies show that the majority of the local people around protected areas have negative feelings about state policies and conservation programmes.

Otieno (2003) notes that the Maasai have co-existed with animals for years, but they never see the proceeds from tourism. Instead, they have become victims of the animals. But how did these negative feelings develop? Factors contributing to conflict involving pastoralists comprise socio-economic and political marginalisation, inadequate land tenure policies, insecurity, cattle rustling, proliferation of small arms and light weapons, weakened traditional governance in pastoral areas, vulnerability to climatic variability, and competition with wildlife. Besides, $70 \%$ of the wild animals live outside official parks in dispersal areas. The wildlife causes an enormous loss to the people by destroying property and killing humans, because there are so many problem animals. Further, wildlife carries many diseases that are dangerous to livestock. These diseases include malignant catarrh fever, a viral disease that kills livestock and is associated with the wildebeest; foot and mouth disease, a highly contagious viral disease that reduces milk supply and body weight; and East Coast fever.

Should the locals still be expected to appreciate the significance of animals even when their interests are not being addressed? Due to the carving out of land for the national parks and reserves, local communities lost invaluable herding resources and sometimes agricultural land. In this instance, local people bear the cost of conservation because of foregoing the opportunity to use their land in alternate ways. Further, the wild animals in the parks usually move in and out of neighbouring farms and ranches in response to spatial and temporal occurrences in the distribution of fodder and water. The rise in human-wildlife conflict could evolve into a major crisis if a solution is not immediately found (Ogodo 2003). 


\section{Roselyne N. Okech}

The lands outside the parks are crucial to wildlife since they serve as dispersal areas. These areas are threatened with increasing 'land sub-division, agricultural expansion and unplanned development of tourist accommodation, thus increasing human-wildlife conflicts' (Kenya 1997:88, cited in Sindiga 1999:21). Amboseli and Maasai Mara provide a good case to examine conflicts between wildlife conservation and local people. The cases provide lessons not only on conflict resolution in conservation but also on the necessity of local support for successful tourism-led conservation. The presence of wildlife which has a capacity to live with many of these diseases without serious impact on their populations is a constant source of frustration to local livestock-keeping. Also, wild animals make cultivation impossible by destroying crops in the fields.

Wildlife in many protected areas (Table 1) is under threat from human encroachment, insularisation, poaching for commercial or subsistence purposes, habitat degradation, encroachment of incompatible land uses, loss of migration and dispersal areas, and ever increasing human-wildlife conflicts. In a scenario where wildlife-induced damages to human property and life are neither controlled nor compensated, negative local attitudes towards conservation and wildlife resources become entrenched (Okello and Wishitemi 2006:90). This is made worse when local communities do not benefit from wildlife resources and are alienated from wildlife-related economic enterprises such as the lucrative tourism industry. When local communities feel that both governments and conservation stakeholders value wildlife more than their lives, livelihoods or their aspirations, retaliation and opposition to conservation initiatives can be swift and uncompromising. One solution to this is to empower communities to manage and benefit from wildlife resources found in communal group ranch dispersal areas. These sanctuaries, for most cases in Kenya, have the tourists in mind as key clients. 
Table 1: The threat factors that operate against biodiversity in Kenya's protected areas, their prevalence and severity as stated by protected area officers

\begin{tabular}{|l|c|c|}
\hline $\begin{array}{l}\text { Threat factor identified by } \\
\text { protected area officers }\end{array}$ & $\begin{array}{l}\text { Number of } \\
\text { protected areas } \\
\text { where the threat } \\
\text { factor exists }\end{array}$ & $\begin{array}{l}\text { Prevalence } \\
\text { Threat } \\
\text { Index (PTI) }\end{array}$ \\
\hline $\begin{array}{l}\text { Illegal killing of wildlife for their bush } \\
\text { meat for the local or regional markets. }\end{array}$ & $48(96 \%)$ & $78,5 \%$ \\
\hline $\begin{array}{l}\text { Danger to biodiversity arising from } \\
\text { the nature and intensity of human- } \\
\text { wildlife conflicts. }\end{array}$ & $41(82 \%)$ & $58,0 \%$ \\
\hline $\begin{array}{l}\text { Large mammal poaching for } \\
\text { international commercial purposes. }\end{array}$ & $40(80 \%)$ & $66,0 \%$ \\
\hline $\begin{array}{l}\text { Human encroachment in terms of } \\
\text { the density and distribution of the } \\
\text { human population around protected } \\
\text { areas. }\end{array}$ & $36(72 \%)$ & $54,0 \%$ \\
\hline $\begin{array}{l}\text { Loss, conversion and degradation } \\
\text { of wildlife migration and dispersal } \\
\text { corridors important for the protected } \\
\text { area. }\end{array}$ & $35(70 \%)$ & $53,5 \%$ \\
\hline $\begin{array}{l}\text { Unsustainable use of, demand for and } \\
\text { over-exploitation of natural resources } \\
\text { (water, plant resources and minerals) } \\
\text { by the local communities. }\end{array}$ & $23(46 \%)$ & $43.5 \%$ \\
\hline $\begin{array}{l}\text { Agricultural expansion and other } \\
\text { land use changes incompatible to } \\
\text { biodiversity requirements. }\end{array}$ & $18(36 \%)$ & \\
\hline
\end{tabular}




\begin{tabular}{|l|c|c|}
\hline $\begin{array}{l}\text { Pollutants from sources external to the } \\
\text { protected area that harm biodiversity } \\
\text { directly or indirectly. }\end{array}$ & $13(26 \%)$ & $21,0 \%$ \\
\hline $\begin{array}{l}\text { Negative tourism impacts on the } \\
\text { welfare of biodiversity and their } \\
\text { habitats. }\end{array}$ & $10(20 \%)$ & $16,5 \%$ \\
\hline $\begin{array}{l}\text { Fencing of an entire protected area } \\
\text { or part of it, and its interference in } \\
\text { wildlife movements. }\end{array}$ & $5(10 \%)$ & $10,0 \%$ \\
\hline
\end{tabular}

Source: Adapted from Okello and Kiringe (2004:59-60)

The potential for tourism expansion, especially in the Tsavo-Amboseli ecosystem, is enormous and is likely to bring higher income to the community if well managed and marketed. However, the increasing network of these communityowned wildlife sanctuaries has to meet some ecological and socio-economic requirements to be viable, acceptable to the local communities and successful. Various threat activities are identified by protected area officers from which 10 main factors threatening biodiversity and conservation are outlined in Table 1.

Illegal killing of wildlife for bush meat occurred in $96 \%$ of the protected areas. Danger to biodiversity arising from human-wildlife conflicts (such as harm to people and property, and retaliatory killing of wildlife) occurred in $82 \%$ of protected areas, followed by large mammal poaching for the international commercial trade in trophies and other animal products which occurred in $80 \%$ of the protected areas. Human encroachment in terms of the density and distribution of the human population around protected areas occurred in $72 \%$ of the protected areas, while loss, conversion and degradation of wildlife migration corridors and dispersal areas occurred in $70 \%$ of the protected areas. In terms of prevalence based on frequency of mention by protected area officers, illegal killing of wildlife for bush meat had a PTI of 78\%. Large mammal poaching for trophies and other products had a PTI of $66 \%$, followed by human-wildlife conflicts with an index of $58 \%$. Human encroachment; and loss, conversion and 
degradation of migration corridors/dispersal area had a PTI of about 54\% each. Other threat factors had a PTI of less than $50 \%$.

The protected areas susceptible to more than $70 \%$ of the identified threat factors were Maasai Mara National Reserve, Ndeere Island National Park, Lake Nakuru National Park, Amboseli National Park, Aberdares National Park, Mount Elgon National Park, Kiunga Marine Park, Mount Kenya National Park, Mombasa Marine Park, Watamu Marine Park, Ruma National Park, Kisite-Mpunguti Marine Park, Malindi Marine Park, Mwea National Reserve, Kamnarok National Reserve, Rimoi National Reserve, and Nairobi National Park. A total of $63 \%$ and $54 \%$ of the protected areas were susceptible to over $50 \%$ and $60 \%$ of the threat factors, respectively. Another $34 \%$ and $6 \%$ were susceptible to over $70 \%$ and $80 \%$ of the threat factors, respectively.

\section{The impact of tourism on biodiversity}

Caalders et al (2000) identified five dimensions that should be considered when measuring the impacts of tourism on biodiversity. They are:

\section{Dimension one: positive versus negative impacts}

Tourism can have both positive and negative impacts on biodiversity. Methods for measuring the impacts of tourism tend to focus on the negative impacts. Positive impacts are, however, substantial.

\section{Dimension two: direct versus indirect impacts}

Tourism can have both direct and indirect impacts. Examples of direct negative impacts are hunting of endangered species, disturbance of animals and trampling on plants. Some indirect negative effects are induced through pollution of the physical environment, decline of the ozone layer, pollution of rivers, and dumping of waste material. On the positive side, indirect effects are the use of park fees for nature conservation and the consciousness raising of both tourists and the local population.

\section{Dimension three: spatial scale}

The spatial scale of impacts can vary from global warming and climate change that have an impact on biodiversity world-wide to trampling that has only 


\section{Roselyne N. Okech}

locally bound effects. In between these two extremes, different levels can be discerned. For example, the pollution of ground water has an impact on the entire downstream drainage area. Effects can be restricted to one ecosystem or to a part thereof. Some may be restricted to areas visited by tourists, others spill over into neighbouring areas. It is important to know whether effects are diffuse, or restricted to the source.

\section{Dimension four: time scale}

Disturbance caused by tourism can be temporary or long lasting. This depends on the type and seriousness of the impact, but also on the vulnerability and recuperative power of the species or the ecosystem.

\section{Dimension five: different types of impacts}

Apart from these general dimensions, different ways in which tourism, or human behaviour, can have an impact on biodiversity can be discerned. In the literature, the following categories have been found: land use and conversion, physical contact, addition of matter, addition of biota, withdrawal of matter, withdrawal of biota, and disturbance.

\section{Policies for resolving wildlife-human conflicts}

According to Okello and Wishitemi (2006:91), a number of changes are taking place among community group ranches in Kenya that threaten the interaction between culture and natural resources. Most of these group ranches, especially among the Maasai, are key wildlife dispersal areas and migration corridors for wildlife. Both internal and external forces drive these changes. The collapse of the beef industry in Kenya and a lack of expertise in livestock husbandry have led to the decline of pastoralism as a means of economic livelihood for the Maasai. As a result, poverty has increased, and has been enhanced by ecological constraints of the area (shallow soils and low rainfall that cannot support agriculture except around swamps and along rivers). Due to lack of government incentives and of a properly established beef industry to encourage efficient marketing and pricing for the Maasai livestock, alternative economic means, even though incompatible with cultural and natural resource conservation, have started to gain popularity. 


\section{Wildlife-community conflicts in conservation areas in Kenya}

The impoverishment of the Maasai is obvious and their daily struggle for survival is leading them to embrace agriculture in marginal rangelands and to convert wetlands and riverine habitats into farmlands. The rivers and their scarce water resources are frequently diverted to irrigate horticulture farms that are providing greater direct and significant household income than both pastoralism and conservation combined. The Oloitoktok and Kimana areas are now leading in production of onions, tomatoes and vegetables in Southern Kenya. Studies about land use changes in ecosystems (Okello and Megquier 1999; Okello and Conner 2000; Okello and Hadas 2000) reveal that over 70\% of the local community in the Tsavo-Amboseli Ecosystem now practise both pastoralism and agriculture, with only a few practising pure pastoralism.

Agriculture expansion does not only destroy natural habitats and alter the character of rangeland landscape, but also fuel the human-wildlife conflicts as wild animals destroy crops more frequently than they harm livestock. Over $40 \%$ of group ranch members experience crop damages annually by wildlife compared to only about 21\% who experience livestock losses (Okello and Megquier 1999; Okello and Conner 2000; Okello and Hadas 2000). Annual combined losses of both crops and livestock to wildlife become of more significance and of great concern to local communities as over $64 \%$ of community members incur both crop and livestock losses annually. These losses of crops and livestock to wildlife, as well as human deaths, insecurity and human injury result in reduced support for conservation. However, traditional interaction over the years has created great tolerance for wildlife among the Maasai, with over $62 \%$ of community members still thinking that wildlife should roam freely on their land, and $92 \%$ stating that wildlife conservation is important. But now, a majority of them are supporting land uses that are destructive and incompatible to conservation such as agriculture, and an increasing majority of over $60 \%$ are supporting and demanding group ranch sub-division into individually owned land parcels.

With about $60 \%$ of a local community being illiterate or having a very low level of education, changing attitudes and opinions by creating awareness through formal education may be less successful (Okello and Wishitemi 2006:91). However, partnerships with the local community that target elderly opinion who influence community opinions through informal education and awareness 


\section{Roselyne N. Okech}

may influence attitudes towards wildlife conservation. The ecological and socioeconomic consequences of land use shift to agriculture that will negatively impact on their culture and conservation need to be explained clearly and consistently. The solutions many local communities are seeking to contain the ever-increasing human-wildlife conflicts, in the absence of direct benefit from conservation, seem to be taking the form of 'separation' rather than 'integration' of culture and natural resource conservation. Fencing and/or translocation of wildlife have/has the support of over $75 \%$ of the local communities (Okello and Hull 2001; Okello and Nippert 2001). Major culprits are elephants, lions and baboons as notorious problem animals. Okello and Nippert (2001) observed that as the Maasai continue to incur wildlife-related losses and insecurity rather than benefits, the government and foreign investors continue to draw large amounts of foreign income from parks (Tsavo and Amboseli) through the lucrative tourism industry.

These parks are historically Maasai traditional lands that were taken away from them without compensation or consultation. In view of the significance of wildlife conservation on its own and its tourism value, wildlife-human conflicts will remain a permanent problem in the neighbourhoods of protected areas. As such, the role of policy is to reduce the conflicts to a tolerable level. This involves dealing with problem wildlife and devising mechanisms to allow local people to derive direct benefits from wildlife-based tourism. Such an approach is likely to encourage the residents of those areas to conserve the fauna and flora. The Kenya Wildlife Service (KWS) (1990:41-45) formulated policies to deal with wildlife-human conflicts according to the wildlife and tenure characteristics of land as follows:

- Priority wildlife areas adjacent to the parks. These are wildlife dispersal areas and corridors without which wildlife cannot survive in the parks. These areas have the potential for wildlife-based economic activities, especially tourism. KWS focuses most of its attention on these lands.

- Non-adjacent areas to protected areas but with high conservation value and/or great potential for economic activity based on wildlife. Here KWS policy is to ensure that these areas are protected and that they also are a buffer for the priority wildlife areas. 
- Wildlife-human conflict areas whether adjacent to or far from a park. KWS policy is to separate wildlife from other land uses by means of a barrier where possible.

- Non-adjacent areas, unconnected with any protected area or defined priority wildlife area, without severe conflict but with at present only moderate or low potential for wildlife activity. These are marginal areas of wildlife habitation and are not national priority.

\section{Case study: Laikipia}

Laikipia is one of 17 districts in the Rift Valley region of Kenya. It spans an area of over $9500 \mathrm{~km}^{2}$ and forms part of the $25000 \mathrm{~km}^{2}$ Ewaso ecosystem. The Laikipia plains stretch from the Greta Rift Valley to magnificent escarpments which descend into the Northern Frontier district. These plains are physically diverse and scenically spectacular, covered by open grasslands, basalt hills, lonely kopjes and dense cedar forest, fed by the Ewaso Nyiro and Ewaso Narok rivers. It is a multi-ethnic tribal district which pastoralist communities share with ranchers, farmers, horticulturalists and wildlife conservation areas.

The various indigenous communities have joined together in partnership with settlers and ranchers to create a conservation and wildlife haven. It includes extensive arid and semi-arid lands as well as arable and urban areas. Pressures on water and land resources have increased greatly in recent years, due to increased farming activities, rapid population growth, and periodic drought. Although violent conflicts in Laikipia have not reached the scale or intensity of those in many parts of the Horn of Africa, conflicts involving pastoralists associated with resource competition, cattle rustling, and wide availability of small arms are nevertheless widespread and of increasing concern. It thus provides a useful case study to examine in depth the factors contributing to conflict and the issues and priorities for conflict prevention. Cattle rearing on large commercial ranches and community-owned rangelands has for many years been the lifeblood of the community. As much of Laikipia has traditionally been used for low intensity grazing it has become a cherished haven for big game. The full cross-section of landowners was initially involved in conservation, and the combination of abundant wildlife and exceptional scenic beauty provided the 


\section{Roselyne N. Okech}

basis for many new developments. It is now apparent that without the support of local communities, no meaningful wildlife conservation can be achieved in Kenya (Beresford and Phillips 2000; Okello and Kiringe 2004:56). Many threats arise from the alienation of local communities.

\section{Factors contributing to violent conflicts involving pastoralists}

The patterns of division and conflict in Laikipia and similar regions are complex. There are many factors contributing to the risk of violent conflict involving pastoralists, and these have tended to become mutually reinforcing. Some conflicts within and between pastoralist communities, such as raiding and cattle rustling, have a long history and have to some extent become an aspect of traditional pastoralist culture. However, such 'traditional' conflicts have become increasingly destructive and less manageable. The Laikipia case study reveals a number of specific factors contributing to the risk of such conflicts between pastoralist communities:

- Socio-economic and political marginalisation;

- Inadequate land tenure policies;

- Insecurity;

- Cattle rustling;

- Proliferation of small arms and light weapons;

- Weakened traditional governance in pastoral areas;

- Vulnerability to climatic variability; and

- $\quad$ Competition with wildlife.

Efforts to prevent and reduce violent conflicts involving pastoralists in Laikipia and similar districts need to address each of the factors contributing to conflicts, as outlined above. The development of effective actions to tackle such causes of conflict is clearly challenging in the context of Laikipia or similar regions in Kenya. This of course is bound to take years. However, serious attempts to address these problems can contribute substantially to conflict prevention and management if they are recognised as such by the communities involved, even if they fall short of what is required due to lack of capacity. This goal implies a direct 
focus on tackling the factors contributing to conflicts involving pastoralists, and on enhancing security and preventing such conflicts.

\section{Way forward for Kenya}

Without dispersal areas, most of Kenya's conservation areas cannot effectively and sustainably support viable wildlife populations, and the tourism industry that relies on it. Furthermore, most of the wildlife uses land adjacent to or completely outside protected areas in most parts of the year (Mbugua 1994; Mwangi 1995; Norton-Griffiths 1997; Sindiga 1995, cited in Okello and Kiringe 2004:56). The finding that most of Kenya's protected areas are susceptible to a variety of threat factors implies that biodiversity conservation is facing an everincreasing challenge. The ten threat factors identified earlier are closely linked to the overall problem of human population increase and associated activities, and these, especially among poor rural communities, lead to expansion of agriculture, even in marginal areas, to meet basic needs. Migration corridors and dispersal areas between protected areas or between a protected area and dispersal range continue to diminish. Good examples can be found around Nairobi National Park (Western 1997), Tsavo-Amboseli areas and around Maasai Mara National Reserve (Ottichilo 2000; Voorspuy 1999, cited in Okello and Kiringe 2004:56) where they are taken up for settlement and agriculture. In the process, wildlife habitats and biodiversity in general are also destroyed. This partly precipitates more human-wildlife conflicts and reinforces negative attitudes to wildlife and the conservation of natural resources among local communities.

It is frustrating to local communities because wildlife-induced losses are generally never compensated. To deal with wildlife-related problems, they may persecute wildlife through displacement and illegal killing. It is obvious that controlling human encroachment and associated activities is a difficult endeavour (Osemeobo 1993). Managing population increases, improved livelihoods and poverty reduction can help reduce human impacts within and around protected areas. Involving local communities in sustainable natural resource use and conservation must be encouraged. No rural-based education about the use of such resources will succeed if local community needs and opinions are not met and incorporated in conservation practice and policies 


\section{Roselyne N. Okech}

(Sarkar 1999). If they do not benefit from biodiversity resources, and are not compensated for opportunity costs and wildlife-induced losses, they will not support the conservation of biodiversity. A national land use plan can also help and will put into perspective land use practices that are compatible with the socio-economic needs, natural resource endowment, and ecological and climatic constraints within different regions of the country.

According to Okello and Kiringe (2004:56), there is a general lack of research on the types of threat factors to protected areas, and their prevalence and severity in Kenya. Further, the susceptibility of existing protected areas to these threats is poorly known, and no published comprehensive analysis of the threats is available. The absence of this analysis makes focused conservation efforts difficult. This analysis can be done using two approaches. The first and important step is to identify threat types, their underlying causes, and assess their prevalence. The second step is to make a quantitative assessment of threats by measuring their frequency, intensity and impact on biodiversity and protected areas. In the final analysis the Kenya Wildlife Service needs to enhance the following measures in order to prevent and reduce conflicts:

- Encourage and support policies to enhance the viability of pastoralism;

- Support efforts to address the political marginalisation of pastoralists;

- Enhance coherence engagement with pastoralist regions;

- Support conflict prevention and reduction activities at the district level;

- Support conflict prevention and reduction activities at national level;

- Assist in controlling and reducing small arms;

- Promote security sector reform; and

- Combat cattle rustling.

\section{Conclusion}

Pastoralists are marginalised and impoverished in Laikipia and indeed throughout much of the Horn of Africa, and are particularly vulnerable when droughts or developments limit their already restricted access to water and pasture. Moreover, conflicts involving pastoralists are increasingly widespread 
and damaging. The patterns of these conflicts, and the factors contributing to them, are complex. It is becoming clear that existing policies and measures relating to pastoralists in Laikipia and similar districts in Kenya are inadequate. Efforts to prevent and reduce conflicts need to be fully integrated into government and development programmes throughout the region, and thus also into the co-operation and assistance programmes of donors. There are many ways in which the KWS can assist in preventing and reducing conflicts involving pastoralists in Laikipia and similar districts. They require systematic and concerted attention, and the development of appropriate and effective partnerships with government, pastoralist and other communities involved, and broader civil society groups.

\section{Sources}

Beresford, M. and A. Phillips 2000. Protected landscapes: A conservation model for the $21^{\text {st }}$ century. Forum, 17 (1), pp. 15-26.

Caalders, J., R. van der Dium, G. Boon and H.Q. Rivel 2000. Tourism and biodiversity: Impacts and perspectives on interventions in the Netherlands and Costa Rica. Cambridge, Cambridge University Press.

Irandu, E.M. 2003. Wildlife tourism and local communities in Kenya. Paper presented at ATLAS-Africa Conference, held in Arusha, Tanzania, 20-22 February 2003.

Kenya, Republic of 1997. The Eighth National Development Plan for the period 1997 to 2001. Nairobi, Government Printer.

KWS (Kenya Wildlife Service) 1990. A Policy Framework and Development Programme 1991-1996. Nairobi, Kenya Wildlife Service.

Mbugua, N. 1994. Maasai-Game conflicts: Who has right of way? Sunday Nation, January.

Ministry of Tourism and Wildlife 2007. Draft Wildlife Policy.

Munyori, N.K. 1992a. Information, education and training needs for sustaining tourism. In: Gakahu, C.G. and B.E. Goode eds. Ecotourism and sustainable development in Kenya. Wildlife Conservation International.

Munyori, N. 1992b. Sustained use of wildlife resources for tourism in Kenya. In: Gakahu, C.G. ed. Tourist attitudes and use in Maasai Mara National Reserve. Wildlife Conservation International.

Mwangi, E.M. 1995. Land use planning and coordination study: Protected area system coverage. Final report to the Kenya Wildlife Service, Nairobi, Kenya.

Norton-Griffiths, M. 1997. Why Kenyan conservation is failing. Swara, 19 (6) and 20 (1), pp. 6-8.

Ogodo, O. 2003. Resolving the conflict calls for a tight balancing Act-Legislator. East African Standard Newspaper, Monday 7 July. The Standard Limited. 


\section{Roselyne N. Okech}

Okello, M.M. and A. Megquier 1999. The species and spatial distribution of wildlife on Kuku Group Ranch and associated human-wildlife conflicts. Unpublished Research Report, SFS Centre for Wildlife Management Studies. Fall 1999, Nairobi, Kenya.

Okello, M.M. and K. Conner 2000. Wildlife distribution and densities, and associated humanwildlife conflicts on Kuku Group Ranch, Kenya. Unpublished Research Report SFS Centre for Wildlife Management Studies. Fall 2000, Nairobi, Kenya.

Okello, M.M. and K. Hadas 2000. Animal density and distribution on Kuku Group Ranch and related human-wildlife conflicts. Unpublished Research Report SFS Centre for Wildlife Management Studies. Spring 2000, Nairobi, Kenya.

Okello, M.M. and T.J. Hull 2001. Socio-ecological considerations for the establishment of Kuku Community Conservation Area, Kenya. Paper presented to SAMA Conference on New Techniques in Wildlife Management. Pretoria, South Africa, 2-3 October 2001.

Okello, M.M. and H. Nippert 2001. The ecological and socio-economic potential of Kuku Community Conservation Area, Kenya. Unpublished Research Report. SFS Centre for Wildlife Management Studies. Fall 2001, Nairobi, Kenya.

Okello, M.M. and J.W. Kiringe 2004. Threats to biodiversity and their implications in protected and adjacent dispersal areas of Kenya. Journal of Sustainable Tourism, 12 (1), pp. 54-69.

Okello, M.M. and B.E.L. Wishitemi 2006. Principles for the establishment of community wildlife sanctuaries for ecotourism: Lessons from Maasai Group Ranches, Kenya. African Journal of Business and Economics, 1 (1), pp. 90-109.

Osemeobo, G.J. 1993. Impact of land use on biodiversity preservation in Nigerian natural ecosystems: A review. Natural Resources Journal, 33, pp. 1015-1025.

Otieno, A. 2003. Why locals are turning against animals. East African Standard Newspaper, Monday 7 July. The Standard Limited.

Ottichilo, W. 2000. An analysis of change in the Maasai-Mara ecosystem of Kenya. Unpublished Ph.D. Thesis, Wageningen University, Wageningen, Netherlands.

Sarkar, S. 1999. Wilderness preservation and biodiversity conservation: Keeping divergent goals distinct. Bioscience, 49 (5), pp. 405-411.

Sindiga, I. 1995. Wildlife-based tourism in Kenya: Land use conflicts and government compensation policies over protected areas. Journal of Tourism Studies, 6 (2), pp. 45-55.

Sindiga, I. 1999. Tourism and African development: Change and challenge of tourism in Kenya. Leiden, African Studies Centre.

Sindiyo, J. 1992. Management proposal for the Mara Dispersal Areas. In: Gakahu, C.G. ed. Tourist attitudes and use in Maasai Mara National Reserve. Wildlife Conservation International.

Voorspuy, T. 1999. In safe hands? Threats to Maasai Mara. Swara, 22 (1), pp. 5-7.

Western, D. 1997. Nairobi National Park is slowly being strangled by development. Swara, 19 (6) and 20 (1), pp. 19-20. 